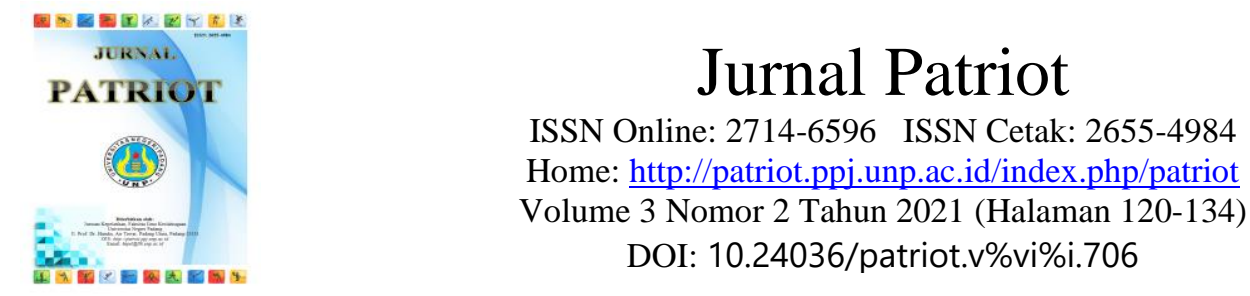

\title{
Kontribusi Daya Ledak Otot Tungkai, Kelentukan dan Keseimbangan terhadap Kemampuan Tendangan Depan Atlet Perguruan Silat Tangan Mas
}

\author{
Rezhi Dwi Andri Zona ${ }^{1}$, M.Ridwan ${ }^{2 *}$, Suwirman ${ }^{3}$, Ronni Yenes ${ }^{4}$ \\ ${ }^{1,2,4}$ Program Studi Pendidikan Kepelatihan Olahraga, Fakultas Ilmu Keolahragaan, Universitas \\ Negeri Padang. \\ ${ }^{3}$ Program Studi Pendidikan Jasmani, Kesehatan dan Rekreasi, Fakultas Ilmu Keolahragaan \\ Univesitas Negeri Padang. \\ Email Korespondensi: m.ridwan@ fik.unp.ac.id
}

Informasi Artikel:

Dikirim: 13 November 2021 Direvisi: 5 Juni 2021 Diterbitkan: 29 Juni 2021

\begin{abstract}
ABSTRAK
Masalah penelitian ini adalah diduga kurangnya kemampuan tendangan depan seperti tendangan yang tidak tepat sasaran, jumlah tendangan yang dikeluarkan tidak mencapai target seharusnya pada atlet perguruan Silat Tangan Mas Lubuk Basung.Variabel dalam penelitian ini adalah daya ledak otot tungkai $\left(\mathrm{X}_{1}\right)$, kelentukan $\left(\mathrm{X}_{2}\right)$, keseimbangan $\left(\mathrm{X}_{3}\right)$ dan kemampuan tendangan depan(Y). Penelitian ini bertujuan untuk mengetahui kontribusi daya ledak otot tungkai, kelentukan, keseimbangan dengan kemampuan tendangan depan. Penelitian ini merupakan jenis penelitian korelasional. Populasi dalam penelitian ini berjumlah 38 orang atlet. Pengambilan sampel diambil dengan menggunakan teknik purposive sampling, dimana yang dijadikan sampel yaitu atlet putra yang berjumlah 22 orang atlet. Instrumen penelitian ini melalui tes standing board jump untuk daya ledak otot tungkai, kelentukan menggunakan tes side split, keseimbangan menggunakan tes modifikasi bass test dan tes kemampuan tendangan depan dilakukan dengan tes kemampuan tendangan depan. Teknik analisa data menggunakan teknik analisis korelasi dan korelasi ganda dolittle dengan taraf signifikan $\alpha=0,05$. Hasil analisis menunjukan: 1) Terdapat kontribusi antara daya ledak otot tungkai terhadap kemampuan tendangan depan sebesar 33\%. 2)Terdapat kontribusi antara kelentukan terhadap kemampuan tendangan depan sebesar 32\%. 3)Terdapat kontribusi antara keseimbangan terhadap kemampuan tendangan depan sebesar 25\%. 4)Terdapat kontribusi antara daya ledak otot tungkai, kelentukan dan keseimbangan secara bersama-sama terhadap kemampuan tendangan depan sebesar $63 \%$. Berdasarkan data yang diperoleh, maka analisa peneliti terhadap penelitian ini adalah terbukti bahwa daya ledak otot tungkai, kelentukan dan keseimbangan secara bersama-sama berkontribusi dengan keterampilan tendangan depan. Dimana daya ledak otot tungkai, kelentukan dan keseimbangan bekerja secara bersama-sama maka keterampilan tendangan depan yang dimiliki juga akan baik, begitu sebaliknya apabila seorang pemain tidak memiliki daya ledak otot tungkai, kelentukan dan keseimbangan yang baik maka keterampilan tendangan depan juga tidak akan baik.
\end{abstract}

Kata Kunci : Pencak Silat; Tendangan Depan; Daya Ledak Otot Tungkai; Kelentukan; Keseimbangan. 
Rezhi Dwi Andri Zona ${ }^{1}$, M.Ridwan², Suwirman ${ }^{3}$, Ronni Yenes ${ }^{4}$

Kontribusi Daya Ledak Otot Tungkai, Kelentukan dan Keseimbangan terhadap Kemampuan Tendangan Depan Atlet Perguruan Silat Tangan Mas

\title{
Contribution of Limb Muscle Explosive Power, Flexibility and Balance to the Front Kick Ability of Perguruan Silat Tangan Mas
}

\begin{abstract}
The problem of this research is the alleged lack of front kick ability such as kicks that are not on target, the number of kicks issued does not reach the target it should be in the Hand Silat college athlete Mas Lubuk Basung. The variables in this study are leg muscle explosive power (X1), flexibility (X2), balance (X3) and front kick ability $(Y)$. This study aims to determine the contribution of leg muscle explosive power, flexibility, balance with front kick ability. This research is a type of correlational research. The population in this study amounted to 38 athletes. Sampling was taken using a purposive sampling technique, where the sample was male athletes, totaling 22 athletes. This research instrument through a standing board jump test for leg muscle explosive power, flexibility using a side split test, balance using a modified bass test and a front kick ability test carried out by a front kick ability test. The data analysis technique used correlation analysis technique and dolittle multiple correlation with a significant level of $=0.05$. The results of the analysis show: 1) There is a contribution of leg muscle explosive power to the front kick ability of $33 \%$. 2) There is a contribution of flexibility to the front kick ability of 32\%. 3) There is a contribution of balance to the front kick ability of 25\%. 4) There is a contribution between leg muscle explosive power, flexibility and balance together to the front kick ability by 63\%. Based on the data obtained, the researcher's analysis of this study is proven that leg muscle explosive power, flexibility and balance simultaneously contribute to front kick skills. Where leg muscle explosive power, flexibility and balance work together, the front kick skills they have will also be good, and vice versa if a player does not have good leg muscle explosive power, flexibility and balance then the front kick skills will also not be good.
\end{abstract}

Keywords: Pencak Silat; Front Kick; Limb Muscle Explosiveness; Flexibility; Balance.

\section{PENDAHULUAN}

Olahraga merupakan suatu aktivitas jasmani yang dilakukan dengan tujuan untuk meningkatkan kemampuan kondisi fisik, mental, maupun rohani dan menjaga tubuh tetap bugar serta tidak cepat mengalami penurunan peforma (Haryanto \& Welis, 2019). Selain untuk menjaga dan meningkatkan kondisi fisik olahraga juga diperuntukkan untuk tujuan lain, seperti untuk ajang rekreasi dan prestasi. Berbagai cabang olahraga sudah diperlombakan untuk tujuan olahraga prestasi, salah satunya yaitu cabang olahraga pencak silat. Perkembangan ilmu pengetahuan dan teknologi (IPTEK) di era globalisasi ini juga membawa dampak kemajuan dalam segala bidang, salah satunya bidang olahraga (Gusfa \& Ridwan, 2018). Perkembangan IPTEK juga mendorong cabang olahraga pencak silat menjadi lebih dikenal dan diminati baik oleh kalangan lokal maupun internasional. Pencak silat sudah menjadi salah satu cabang olahraga prestasi, dalam penguasaan teknik pencak silat harus dikuasai secara baik demi mewujudkan target prestasi yang diinginkan. Sepeti penguasaan teknik tendangan, pukulan, tangkisan, bantingan dan koordinasi geraknya perlu dikuasai dengan baik. Jika salah satu teknik tidak dikuasai dengan baik akan berpengaruh 
Rezhi Dwi Andri Zona ${ }^{1}$, M.Ridwan², ${ }^{2}$ Suwirman ${ }^{3}$, Ronni Yenes ${ }^{4}$

Kontribusi Daya Ledak Otot Tungkai, Kelentukan dan Keseimbangan terhadap Kemampuan Tendangan Depan Atlet Perguruan Silat Tangan Mas

pada peningkatan prestasi. Seperti yang ditemukan dalam penelitian ini dimana para atlet kurang menguasai kemampuan tendangan depan yang menjadi salah satu penghambat untuk bisa meraih prestasi maksimal atau target prestasi yang ingin dicapai.

Untuk mencapai prestasi dalam olahraga bukanlah pekerjaan yang mudah, diperlukan usaha maksimal untuk meraih prestasi tersebut, dimana dalam pembinaan olahraga prestasi ini terdapat pengembangan yang terencana, berjenjang dan berkelanjutan serta di dukung dengan IPTEK dibidang keolahragaan (Mahandra \& Ridwan, 2019). Untuk meraih dan mencapai prestasi dalam suatu cabang olahraga, perlu dilakukan kerjasama yang terarah dan memperhatikan segala aspek yang ikut mendukung tercapainya prestasi tersebut (Maizan \& Umar, 2020). Untuk meraih puncak prestasi atlet harus melalui tahap yang dinamakan latihan. Karena tanpa latihan atlet tidak akan mampu mengembangkan potensi dirinya untuk dapat mencapai puncak prestasi yang ditargetkan (Chan \& Aziz, 2020). Pemberian beban dalam pelaksanaan latihan dimaksudkan agar latihan tersebut memberikan hasil (Nurahman \& Ridwan, 2019). Dalam penelitian lebih lanjut, untuk memaksimalkan proses latihan perlu melakukan pemanasan untuk kesiapan motorik atlet memasuki fase inti latihan (Hunter \& Marshall, 2002). Keberhasilan prestasi yang diraih ditunjukkan seorang atlet dalam suatu kompetisi, terutama ditentukan dan dipengaruhi oleh kemampuan atlet itu sendiri secara terpadu (Putra \& Afrizal, 2020). Beberapa faktor seperti kualitas kondisi fisik, keterampilan dan penggunaan teknik serta kematangan suatu teknik itu sendiri dapat mempengaruhi keberhasilan pesilat dalam suatu (R, D, \& Syampurma, 2019). Kemampuan yang harus dimiliki setiap pesilat untuk menunjang dalam mewujudkan prestasi maksimal yaitu kemampuan teknik dan gerak dasar yang baik. Dalam mencapai presetasi, seorang pesilat harus menguasai semua unsur dan berbagai teknik dasar dalam pencak silat seperti tendangan, pukulan, elakan dan gerak dasar lainnya (Ihsan, Zulman, \& Adriansyah, 2018). Gerakan dalam setiap cabang olahraga sangat penting bagi pengembangan kemampuan bawaan yang dimiliki (Aziz \& Donie, 2017).

Terdapat berbagai macam gerakan dan teknik dalam pencak silat, namun hanya beberapa yang bisa boleh digunakan dalam pertandingan seperti tendangan depan, tendangan sabit, tendangan samping (T) dan tendangan belakang. Pada pertandingan laga $(f i g h t)$ dalam pencak silat, tendangan merupakan teknik yang lebih dominan untuk menghasilkan angka dan mencetak poin agar lebih unggul dari lawan. Kemampuan dalam menerapkan teknik tendangan secara cepat dan akurat harus dimiliki setiap atlet sehingga bisa disebut teknik kemampuan khusus. Kemampuan tendangan depan yang baik merupakan salah satu syarat yang harus dikuasai oleh setiap atlet untuk melakukan serangan dan merupakan salah satu faktor penentu dalam meraih angka dan kemenangan. Terdapat beberapa faktor yang mempengaruhi prestasi atlet yaitu; penguasaan teknik, kondisi fisik, psikologis, taktik/strategi dalam bertanding (Wahyuni \& Donie, 2020). 
Rezhi Dwi Andri Zona ${ }^{1}$, M.Ridwan², ${ }^{2}$ Suwirman ${ }^{3}$, Ronni Yenes ${ }^{4}$

Kontribusi Daya Ledak Otot Tungkai, Kelentukan dan Keseimbangan terhadap Kemampuan Tendangan Depan Atlet Perguruan Silat Tangan Mas

Dalam upaya peningkatan prestasi atlet terdapat beberapa faktor lain yang mempengaruhi seperti faktor internal, diantaranaya pengaruh kondisi fisik, penguasaan teknik yang benar, dan faktor eksternal seperti sarana dan prasarana, dukungan dari lingkungan dan juga kecukupan gizi atlet. Gizi dibutuhkan untuk aktivitas yang berhubungan dengan kemampuan motorik (Solissa, 2017). Asupan gizi ikut berpengaruh terhadap prestasi atlet, karena gizi yang baik merupakan syarat utama kondisi tubuh agar teteap prima sehingga dapat mencapai prestasi masksimal (Sepriadi \& Neldi, 2018). Untuk melakukan berbagai teknik pencak silat dengan baik diperlukan kondisi fisik yang prima yang juga ditunjang dari komponen gizi seimbang yang dikonsumsi atlet. Kecukupan gizi yang dikonsumsi atlet secara langsung berpengaruh terhadap aktivitas fisik motorik. Selain itu bentuk latihan yang dipilih juga berperan dalam menentukan pencapaian dari target latihan (Zulfahmi, Padli, Alnedral, \& Sari, 2020).

Latihan yang dijalani atlet juga harus dilakukan dengan kondisi fisik yang prima. Kondisi fisik atlet perguruan silat yang menurun dipaparkan oleh pelatih dikarenakan kurangnya kedisiplinan dari diri atlet dalam berlatih, seperti datang tidak tepat waktu. Selain itu atlet juga tidak disiplin dalam berlatih, dimana atlet hanya berlatih jika ia ingin sehingga program latihan dari pelatih tidak berjalan sebagaimana mestinya sehingga peningkatan untuk kemampuan terhadap tendangan depan masih kurang dari target yang diharapkan. Dalam penguasaan teknik juga belum bersih sehingga mempengaruhi ketika melakukan teknik tendangan depan. Jika fisik dan teknik terganggu maka taktik yang diterapkan pelatihpun akan sia-sia sehingga penampilan prestasi tidak dapat mencapai titik maksimal (Hidayat \& Argantos, 2020).

\section{METODE}

Penelitian ini merupakan jenis penelitian korelasional. Populasi dalam penelitian ini berjumlah 38 orang atlet. Pengambilan sampel diambil dengan menggunakan teknik purposive sampling, dimana yang dijadikan sampel yaitu atlet putra yang berjumlah 22 orang atlet. Instrumen penelitian ini melalui tes standing board jump untuk daya ledak otot tungkai, kelentukan menggunakan tes side split, keseimbangan menggunakan tes modifikasi bass test dan tes kemampuan tendangan depan dilakukan dengan tes kemampuan tendangan depan. Penelitian ini dilaksanakan pada 12-13 Agustus 2020 di Perguruan Silat Tangan Lubuk Basung, pada masa New Normal dengan daerah tempat penelitian diadakan masih dalam zona aman. Teknik analisa data menggunakan teknik analisis korelasi dan korelasi ganda dolittle dengan taraf signifikan $\alpha=0,05$. 
Rezhi Dwi Andri Zona ${ }^{1}$, M.Ridwan², Suwirman ${ }^{3}$, Ronni Yenes ${ }^{4}$

Kontribusi Daya Ledak Otot Tungkai, Kelentukan dan Keseimbangan terhadap Kemampuan Tendangan

Depan Atlet Perguruan Silat Tangan Mas

\section{HASIL}

1. Daya Ledak Otot Tungkai $\left(\mathrm{X}_{1}\right)$

Berdasarkan hasil tes daya ledak otot tungkai, diperoleh skor maksimum adalah 250 dan skor minimum 195. Disamping itu diperoleh nilai rata-rata (mean) sebesar 219,32 dan standart deviasi sebesar 12,01. Agar lebih jelasnya deskripsi data daya ledak otot tungkai dapat dilihat pada tabel 2 dibawah ini:

Tabel 1. Distribusi Frekuensi Daya Ledak Otot Tungkai $\left(\mathrm{X}_{1}\right)$

\begin{tabular}{ccccc}
\hline \multirow{2}{*}{ No. } & Kelas Interval & \multicolumn{2}{c}{ Frekuensi } & Kategori \\
& & Fa & Fr & \\
\hline 1. & $237-248$ & 2 & $9.09 \%$ & Baik Sekali \\
2. & $225-236$ & 5 & $22.73 \%$ & Baik \\
3. & $213-224$ & 9 & $40.91 \%$ & Cukup \\
4. & $201-212$ & 5 & $22.73 \%$ & Kurang \\
5. & $189-200$ & 1 & $4.55 \%$ & Kurang Sekali \\
& Jumlah & $\mathbf{2 2}$ & $\mathbf{1 0 0 \%}$ & \\
\hline
\end{tabular}

Berdasarkan tabel diatas dari 22 orang sampel, 2 orang $(9,09 \%)$ memiliki daya ledak otot tungkai berkisar antara 237-248 berada dikategori baik sekali, 5 orang $(22,73 \%)$ memiliki daya ledak otot tungkai berkisar antara 225-236 berada dikategori baik, 9 orang $(40,91 \%)$ memiliki daya ledak otot tungkai berkisar antara 213-224 berada dikategori cukup, 5 orang $(22,73 \%)$ memiliki daya ledak otot tungkai berkisar antara 201-212 berada di kategori kurang, dan 1 orang $(4,55 \%)$ memiliki daya ledak otot tungkai berkisar antara 189-200 berada dikategori kurang sekali.

2. Kelentukan $\left(\mathrm{X}_{2}\right)$

Berdasarkan hasil tes kelentukan, diperoleh skor maksimum adalah 13 dan skor minimum 1. Disamping itu diperoleh nilai rata-rata (mean) sebesar 5,91 dan standart deviasi sebesar 3,50. Agar lebih jelasnya deskripsi data kelentukan dapat dilihat pada tabel 3 dibawah ini:

Tabel 2. Distribusi Frekuensi Kelentukan $\left(\mathrm{X}_{2}\right)$

\begin{tabular}{ccccc}
\hline \multirow{2}{*}{ No. } & Kelas Interval & Fa & Fr & Kategori \\
\hline 1. & $0-2$ & 5 & 22.73 & Baik Sekali \\
2. & $3-5$ & 5 & 22.73 & Baik \\
3. & $6-8$ & 6 & 27.27 & Cukup \\
4. & $9-11$ & 5 & 22.73 & Kurang \\
5. & $12-14$ & 1 & 4.55 & Kurang Sekali \\
& Jumlah & $\mathbf{2 2}$ & $\mathbf{1 0 0}$ & \\
\hline
\end{tabular}


Berdasarkan tabel diatas dari 22 orang sampel, 5 orang $(22,73 \%)$ memiliki kelentukan berkisar antara 0 -2 berada dikategori baik sekali, 5 orang $(22,73 \%)$ memiliki kelentukan berkisar antara 3-5 berada dikategori baik, 6 orang $(27,27 \%)$ memiliki kelentukan berkisar antara 6-8 berada dikategori cukup, 5 orang $(22,73 \%)$ memiliki kelentukan berkisar antara 9-11 berada di kategori kurang, dan 1 orang $(4,55 \%)$ memiliki kelentukan berkisar antara 12-14 berada di kategori kurang sekali.

3. Keseimbangan $\left(\mathrm{X}_{3}\right)$

Berdasarkan hasil keseimbangan, diperoleh skor maksimum adalah 93 dan skor minimum 83. Disamping itu diperoleh nilai rata-rata (mean) sebesar 88,18 dan standart deviasi sebesar 3,10. Agar lebih jelasnya deskripsi data keseimbangan dapat dilihat pada tabel 4 dibawah ini:

Tabel 3. Distribusi Frekuensi Keseimbangan $\left(\mathrm{X}_{3}\right)$

\begin{tabular}{ccccc}
\hline & & \multicolumn{2}{c}{ Frekuensi } & \\
No. & Kelas Interval & Fa & Fr & Kategori \\
\hline 1. & $93-95$ & 2 & 9.09 & Baik Sekali \\
2. & $90-92$ & 6 & 27.27 & Baik \\
3. & $87-89$ & 8 & 36.36 & Cukup \\
4. & $84-86$ & 5 & 22.73 & Kurang \\
5. & $81-83$ & 1 & 4.55 & Kurang Sekali \\
& Jumlah & $\mathbf{2 2}$ & $\mathbf{1 0 0}$ & \\
\hline
\end{tabular}

Berdasarkan tabel diatas dari 22 orang sampel, 2 orang $(9,09 \%)$ memiliki keseimbangan berkisar antara 93-95, 6 orang $(27,27 \%)$ memiliki keseimbangan berkisar antara $90-92,8$ orang $(36,36 \%)$ memiliki keseimbangan berkisar antara $87-89,5$ orang $(22,73 \%)$ memiliki keseimbangan berkisar antara $84-86$, dan 1 orang $(4,55 \%)$ memiliki keseimbangan berkisar antara 81-83.

4. Tendangan Depan (Y)

Berdasarkan hasil tes tendangan depan, diperoleh skor maksimum adalah 55 dan skor minimum 29. Disamping itu diperoleh nilai rata-rata (mean) sebesar 39,86 dan standart deviasi sebesar 7,49. Agar lebih jelasnya deskripsi data tendangan depan dapat dilihat pada tabel 5 dibawah ini: 
Tabel 4. Distribusi Frekuensi Tendangan Depan (Y)

\begin{tabular}{ccccc}
\hline \multirow{2}{*}{ No. } & Kelas nterval & Fa & Fr & Kategori \\
\hline 1. & $51-57$ & 2 & 9.09 & Baik Sekali \\
2. & $44-50$ & 5 & 22.73 & Baik \\
3. & $36-43$ & 7 & 31.82 & Cukup \\
4. & $29-35$ & 8 & 36.36 & Kurang \\
5. & $21-28$ & 0 & 0 & Kurang Sekali \\
& Jumlah & $\mathbf{2 2}$ & $\mathbf{1 0 0}$ & \\
\hline
\end{tabular}

Berdasarkan tabel diatas dari 22 orang sampel, 2 orang $(9,09 \%)$ memiliki tendangan depan berkisar antara 51-57 berada dikategori baik sekali, 5 orang $(22,73 \%)$ memiliki tendangan depan berkisar antara $44-50$ berada dikategori baik, 7 orang $(31,2 \%)$ memiliki tendangan depan berkisar antara 36-43 berada dikategori cukup, 8 orang (36,36\%) memiliki tendangan depan berkisar antara 29-35 berada dikategori kurang, dan tidak ditemukan orang memiliki tendangan depan berkisar antara 21-28 berada dikategori kurang sekali.

5. Pengujian Persyaratan Analisis

a. Uji Normalitas

Tabel 5. Rangkuman Uji Normalitas Sebaran Data

\begin{tabular}{cccccc}
\hline No & Variabel & $\mathrm{N}$ & $\mathrm{L}_{\mathrm{o}}$ & $\mathrm{L}_{\text {tab }}$ & Distribusi \\
\hline 1 & Daya ledak otot tungkai $\left(\mathrm{X}_{1}\right)$ & 22 & 0,1449 & 0,190 & Normal \\
2 & Kelentukan $\left(\mathrm{X}_{2}\right)$ & 22 & 0,1149 & 0,190 & Normal \\
3 & Keseimbangan $\left(\mathrm{X}_{3}\right)$ & 22 & 0,1212 & 0,190 & Normal \\
3 & Tendangan Depan $(\mathrm{Y})$ & 22 & 0,1530 & 0,190 & Normal \\
\hline
\end{tabular}

Berdasarkan tabel di atas ternyata semua variabel $\left(\mathrm{X}_{1}, \mathrm{X}_{2}, \mathrm{X}_{3}\right.$ dan $\left.\mathrm{Y}\right)$ data tersebut tersebar secara normal, karena masing-masing variabel skor $\mathrm{L}_{\mathrm{o}}$ nya lebih kecil dari pada $\mathrm{L}_{\text {tab }}$ pada taraf pengujian signifikan $\alpha=0,05$. Hal ini signifikan bahwa data masing-masing variabel penelitian ini tersebut normal atau populasi dari mana data sampel diambil berdistribusi normal. 
b. Uji Signifikan

1. Kontribusi Daya Ledak Otot Tungkai $\left(\mathrm{X}_{1}\right)$ terhadap Kemampuan Tendangan Depan.

Sedangkan untuk menguji signifikan koefisien korelasi antara daya ledak otot tungkaidengan kemampuan tendangan depanadalah dengan menggunakan rumus $: t=\frac{r \sqrt{n-2}}{\sqrt{1-r^{2}}}$. Dari hasil analisis statistik yang dilakukan diperoleh $\mathrm{t}$ hitung $=3,43$ dan $\mathrm{t}$ Tabel $=1,72$, karena $t$ hitung $>t$ Tabel maka dapat disimpulkan terdapat hubungan yang signifikan antara $\mathrm{X}_{1}$ dengan $\mathrm{Y}$.

2. Kontribusi Kelentukan $\left(\mathrm{X}_{2}\right)$ terhadap Kemampuan Tendangan Depan.

Sedangkan untuk menguji signifikan koefisien korelasi antara kelentukan dengan kemampuan tendangan depanadalah dengan menggunakan rumus $: t=\frac{r \sqrt{n-2}}{\sqrt{1-r^{2}}}$. Dari hasil analisis statistik yang dilakukan diperoleh $t$ hitung $=3,36$ dan $t$ table $=1,72$, karena $t_{\text {hitung }}>$ dari $t$ Tabel maka dapat disimpulkan terdapat hubungan yang signifikan antara $\mathrm{X}_{2}$ dengan $\mathrm{Y}$

3. Kontribusi Keseimbangan $\left(\mathrm{X}_{3}\right)$ terhadap Kemampuan Tendangan Depan.

Sedangkan untuk menguji signifikan koefisien korelasi antara keseimbangan dengan kemampuan tendangan depan adalah dengan menggunakan rumus $: t=$ $\frac{r \sqrt{n-2}}{\sqrt{1-r^{2}}}$. Dari hasil analisis statistik yang dilakukan diperoleh $\mathrm{t}$ hitung $=3,68$ dan $\mathrm{t}$ Tabel $=1,72$, karena $\mathrm{t}$ hitung $>\mathrm{t}$ Tabel maka dapat disimpulkan terdapat hubungan yang signifikan antara $\mathrm{X}_{3}$ dengan $\mathrm{Y}$.

4. Uji Signifikansi Korelasi Ganda

Pengujian signifikansi korelasi gandadiperoleh $F_{\text {hitung }}=4,02$ dan $F_{\text {Tabel }}=3,16$ maka hasilnya ialah $\mathrm{H}_{\mathrm{o}}$ ditolak, $\mathrm{H}_{\mathrm{a}}$ diterima. Karena $\mathrm{F}_{\text {hitung }}>\mathrm{F}_{\text {Tabel }}$ sehingga kesimpulannya terdapat hubungan yang berarti antara antara daya ledak otot tungkai, kelentukan dan keseimbangan secara bersama-sama dengankemampuan tendangan depan.

6. Pengujian Hipotesis

a. Hipotesis Satu $\left(\mathrm{X}_{1}\right.$ dan $\left.\mathrm{Y}\right)$ Kontribusi Daya Ledak Otot Tungkai terhadap Kemampuan Tendangan Depan Atlet Perguruan Silat Tangan Mas Lubuk Basung

Hipotesis pertama yang diajukan dalam penelitian ini adalah terdapat kontribusi antara daya ledak otot tungkai terhadap kemampuan tendangan depan atlet perguruan Silat Tangan Mas Lubuk Basung. Untuk mengetahui kontribusi ini pertama sekali dilakukan analisis korelasi sederhana Hasil perhitungan menunjukkan bahwa koefisien korelasi antara daya ledak otot tungkai terhadap keterampilan tendangan depan adalah positif, hal ini terlihat bahwa dari analisis statistik yang dilakukan

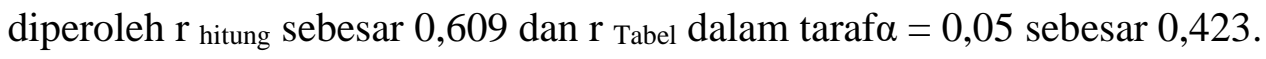


Untuk mengetahui besarnya koefisien determinasi daya ledak otot tungkai terhadap keterampilan tendangan depan. Dari hasil analisis statistik yang dilakukan diperoleh nilai Koefisien korelasi B1.k x r1.k $(0.534 \times 0.609)=0,325 \times 100 \%$ berarti daya ledak otot tungkai memberikan kontribusi dengan keterampilan tendangan depan sebesar 33\%. Oleh sebab itu hipotesis pertama dalam penelitian ini diterima kebenarannya secara empiris.

b. Hipotesis Dua $\left(\mathrm{X}_{2}\right.$ dan $\left.\mathrm{Y}\right)$ Kontribusi Kelentukan terhadap Kemampuan Tendangan Depan Atlet Perguruan Silat Tangan Mas Lubuk Basung

Hipotesis kedua yang diajukan dalam penelitian ini adalah terdapat kontribusi antara kelentukan terhadap kemampuan tendangan depan atlet perguruan Silat Tangan Mas Lubuk Basung. Untuk mengetahui kontribusi ini pertama sekali dilakukan analisis korelasi sederhana. Hasil perhitungan menunjukkan bahwa koefisien korelasi antara kelentukan terhadap keterampilan tendangan depanadalah positif, hal ini terlihat bahwa dari analisis statistik yang dilakukan diperoleh $\mathrm{r}$ hitung sebesar 0,601 dan $\mathrm{r}$ Tabel dalam taraf $\alpha=0,05$ sebesar 0,423 .

Untuk mengetahui besarnya koefisien determinasi kelentukan terhadap keterampilan tendangan depan. Dari hasil analisis statistik yang dilakukan diperoleh nilai Koefisien korelasi B1.k x r1.k $(0.538 \times 0.601)=0,323 \times 100 \%$ berarti kelentukan memberikan kontribusi dengan keterampilan tendangan depan sebesar 32\%. Oleh sebab itu hipotesis kedua dalam penelitian ini diterima kebenarannya secara empiris.

c. Hipotesis Tiga ( $\mathrm{X}_{3}$ dan $\left.\mathrm{Y}\right)$ Keseimbangan terhadap Kemampuan Tendangan Depan Atlet Perguruan Silat Tangan Mas Lubuk Basung

Hipotesis ketiga yang diajukan dalam penelitian ini adalah terdapat kontribusi antara keseimbangan terhadap kemampuan tendangan depan atlet perguruan Silat Tangan Mas Lubuk Basung. Untuk mengetahui kontribusi ini pertama sekali dilakukan analisis korelasi sederhana. Hasil perhitungan menunjukkan bahwa koefisien korelasi antara keseimbangan dengan keterampilan tendangan depan adalah positif, hal ini terlihat bahwa dari analisis statistik yang dilakukan diperoleh $\mathrm{r}$ hitung sebesar 0.636 dan $\mathrm{r}$ Tabel dalam taraf $\alpha=0,05$ sebesar 0,423 .

Untuk mengetahui besarnya koefisien determinasi keseimbangan dengan keterampilan tendangan depan. Dari hasil analisis statistik yang dilakukan diperoleh nilai Koefisien korelasi B1.k x r1.k $(0.389 \times 0.636)=0,247 \times 100 \%$ berarti keseimbangan memberikan kontribusi dengan keterampilan tendangan depan sebesar $25 \%$. Oleh sebab itu hipotesis kedua dalam penelitian ini diterima kebenarannya secara empiris. 
d. Hipotesis Empat $\left(\mathrm{X}_{1} \mathrm{X}_{2} \mathrm{X}_{3}\right.$ dan $\left.\mathrm{Y}\right)$ Daya Ledak Otot Tungkai, Kelentukan Kecepatan dan Keseimbangan terhadap Kemampuan Tendangan Depan Atlet Perguruan Silat Tangan Mas Lubuk Basung.

Hipotesis keempat yang diajukan dalam penelitian ini adalah terdapat kontribusi antara daya ledak otot tungkai, kelentukan kecepatan dan keseimbangan terhadap kemampuan tendangan depan atlet perguruan Silat Tangan Mas Lubuk Basung.Untuk mengetahui kontribusi ini pertama sekali dilakukan analisis korelasi sederhana. Hasil perhitungan menunjukkan bahwa koefisien korelasi antara daya ledak otot tungkai, kelentukan kecepatan dan keseimbangan terhadap keterampilan tendangan depan adalah positif, hal ini terlihat bahwa dari analisis statistik yang dilakukan diperoleh $\mathrm{r}_{\text {hitung }}$ sebesar 0,634 dan $\mathrm{r}_{\text {Tabel }}$ dalam taraf $\alpha=0,05$ sebesar 0,423.

Untuk mengetahui besarnya koefisien determinasi daya ledak otot tungkai, kelentukan kecepatan dan keseimbangan terhadap keterampilan tendangan depan. Dari hasil analisis statistik yang dilakukan berarti kecepatan, kelincahan dan keseimbangan dengan kemampuan dribbling sebesar 63\%. Oleh sebab itu hipotesis keempat dalam penelitian ini diterima kebenarannya secara empiris.

\section{PEMBAHASAN}

1. Kontribusi Daya Ledak Otot Tungkai terhadap Kemampuan Tendangan Depan Atlet Perguruan Silat Tangan Mas Lubuk Basung

Berdasarkan hasil perhitungan analisis korelasi sederhana untuk data menunjukkan bahwa terdapat hubungan daya ledak otot tungkai dengan kemampuan tendangan depan. Karena diperoleh $\mathrm{r}_{\text {hitung }}$ sebesar 0,609 dan $\mathrm{r}_{\text {tabel }}$ dalam taraf $\alpha=0,05$ sebesar 0,423 dengan demikian $\mathrm{r}_{\text {hitung }}>\mathrm{r}_{\text {tabel }}$. Hasil penelitian membuktikan bahwa terdapat kontribusi antara daya ledak otot tungkai dengan kemampuan tendangan depandengan kontribusi sebesar $=33 \%$. Artinya dapat memberikan daya ledak otot tungkai dengan kemampuan tendangan depan atlet perguruan silat Tangan Mas Lubuk Basung.

Pada sebagian besar cabang olahraga, kemampuan untuk menghasilkan dan mengunakan daya ledak merupakan salah satu kunci kesuksesan (Stockbrugger \& Haennel, 2003). Daya ledak (explosive power) merupakan elemen kondisi fisik khusus yang mana dihasilkan dari perpaduan kekuatan dan kecepatan (Ridwan \& Sumanto, 2017). Dapat diartikan daya ledak adalah kemampuan untuk melakukan kerja motorik otot dalam dengan kuat dalam tempo waktu yang cepat. . Kekuatan otot tungkai yang dihasilkan dari kerjasama sekelompok motorik otot untuk bergerak (Maidarman, 2016).

Daya ledak otot tungkai merupakan kemampuan otot tungkai untuk menahan beban dalam melakukan suatu aktivitas. Dalam pencak silat, tendangan yang dilakukan oleh pesilat harus kuat dan cepat agar tendangan tersebut tidak mudah untuk diantisipasi 
Rezhi Dwi Andri Zona ${ }^{1}$, M.Ridwan², ${ }^{2}$ Suwirman ${ }^{3}$, Ronni Yenes ${ }^{4}$

Kontribusi Daya Ledak Otot Tungkai, Kelentukan dan Keseimbangan terhadap Kemampuan Tendangan

Depan Atlet Perguruan Silat Tangan Mas

oleh lawan sehingga dapat memberikan poin bagi pesilat, oleh sebab itu tendangan depan dapat dilakukan dengan baik apabila didukung oleh kemampuan daya ledak otot tungkai yang baik.

2. Kontribusi Kelentukan terhadap Kemampuan Tendangan Depan Atlet Perguruan Silat Tangan Mas Lubuk Basung

Berdasarkan hasil perhitungan analisis korelasi sederhana menunjukan bahwa terdapat hubungan kelentukan dengan kemampuan tendanngan depan, oleh karena itu berarti terdapat hubungan yang berarti antara kelentukan dengan kemampuan tendanngan depan. Karena diperoleh $\mathrm{r}_{\text {hitung }}$ sebesar 0,601 dan $\mathrm{r}_{\text {tabel }}$ dalam taraf $\alpha=0,05$ sebesar 0,423 dengan demikian $r_{\text {hitung }}>r_{\text {tabel }}$. Hasil penelitian membuktikan bahwa terdapat kontribusi antara kelentukan dengan kemampuan tendanngan depan dengan kontribusi sebesar $=32 \%$. Artinya kelentukan dapat memberikan kontribusi dengan kemampuan tendanngan depanatlet perguruan silat Tangan Mas Lubuk Basung.

Komponen kondisi fisik ini berperan untuk menunjang ketepatan seorang pesilat saat melakukan tendangan. Kemampuan tendangan depan membutuhkan kelentukan yang baik sebab apabila pada saat melakukan tendangan depan kelentukan tidak baik maka hasil tendangan depan tidak akan maksimal, ruang gerak terbatas bahkan akan mengakibatkan cedera. Beberapa cabang olahraga kelentukan berperan cukup besar bagi atlet dan sering kali salah satu kemampuan ini menjadi kunci peluang untuk menang (Sands, Mcneal, Stone, Russell, \& Jemni, 2006). Untuk menghasilkan atlet dengan skill yang bagus perlu diperhatikan bagian perkembangan komponen mototrik sejak usia dini (Ricotti L. , 2011). Kelentukan merupakan kemampuan motorik untuk melakukan latihan-latihan dengan amplitudo gerakan yang besar dan luas (Ambia \& Ridwan, 2019). Keberhasilan melakukan suatu gerakan dipengaruhi oleh amplitudo sendi serta luas gerakan yang melebihi kebutuhan kelentukan gerakan (S, 2018). Peregangan yang tepat akan meningkatkan fleksibilitas yang berguna mencegah cidera pada otot saat berolahraga (Dadebo, White, \& George, 2004). Oleh karena itu seorang pesilat membutuhkan kelentukan yang baik agar kemampuan tendangan depan dapat dilakukan dengan sempurna.

3. Kontribusi Keseimbangan terhadap Kemampuan Tendangan Depan Atlet Perguruan Silat Tangan Mas Lubuk Basung

Berdasarkan hasil perhitungan analisis korelasi sederhana menunjukan bahwa terdapat hubungan keseimbangan dengan kemampuan tendangan depan, oleh karena itu berarti terdapat hubungan yang berarti antara keseimbangan dengan kemampuan tendangan depan. Karena diperoleh $\mathrm{r}_{\text {hitung }}$ sebesar 0,636 dan $\mathrm{r}_{\text {tabel }}$ dalam taraf $\alpha=0,05$ sebesar 0,423 dengan demikian $r_{\text {hitung }}>\mathrm{r}_{\text {tabel }}$. Hasil penelitian membuktikan bahwa terdapat kontribusi antara keseimbangan dengan kemampuan tendangan depan dengan kontribusi sebesar $=25 \%$. 
Rezhi Dwi Andri Zona ${ }^{1}$, M.Ridwan², ${ }^{2}$ Suwirman ${ }^{3}$, Ronni Yenes ${ }^{4}$

Kontribusi Daya Ledak Otot Tungkai, Kelentukan dan Keseimbangan terhadap Kemampuan Tendangan Depan Atlet Perguruan Silat Tangan Mas

Keseimbangan merupakan kemampuan tubuh untuk bertahan pada suatu posisi dalam waktu yang lama (Yenes, 2018). Setiap orang sangat memerlukan keseimbangan yang dapat mempertahankan stabilitas posisi tubuh dalam kondisi statis maupun dinamis baik itu anak-anak maupun orang dewasa.

Ketika melakukan teknik tendangan seorang atlet membutuhkan keseimbangan yang baik untuk berdiri atau bertumpu pada satu kaki (Hardiansyah, 2019). Berdasarkan penjelasan diatas kondisi fisik keseimbangan sangat dibutuhkan dalam gerakan kemampuan tendangan depan. Tanpa keseimbangan yang baik atlet akan mudah kehilangan kendali ketika melakukan teknik tendangan depan. Oleh sebab itu latihan keseimbangan harus diperhatikan oleh setiap pelatih karena keseimbangan merupakan hal yang sangat penting dalam suatu gerakan dalam bermain pencak silat khususnya pada gerakan kemampuan tendangan depan.

4. Terdapat Kontribusi Daya Ledak Otot Tungkai, Kelentukan dan Keseimbangan terhadap Kemampuan Tendangan Depan Atlet Perguruan Silat Tangan Mas Lubuk Basung.

Hasil perhitungan analisis korelasi ganda dolittle menunjukan bahwa korelasi terdapat hubungan daya ledak otot tungkai, kelentukan dan keseimbangan dengan kemampuan tendangan depan atlet perguruan silat Tangan Mas Lubuk Basung, oleh karena itu berarti terdapat hubungan yang berarti antara daya ledak otot tungkai, kelentukan dan keseimbangan dengan kemampuan tendangan depan.Hasil penelitian membuktikan bahwa terdapat kontribusi antara daya ledak otot tungkai, kelentukan dan keseimbangan dengan kemampuan tendangan depan dengan kontribusi sebesar $=63 \%$.

Berdasarkan hal ini, maka menurut analisa peneliti terhadap penelitian ini adalah terbukti bahwa daya ledak otot tungkai, kelentuka dan keseimbangan secara bersamasama berkontribusi dengan kemampuan tendangan depan. Dimana daya ledak otot tungkai, kelentuka dan keseimbangan bekerja secara bersama-sama maka kemampuan tendangan depan yang dimiliki juga akan baik, begitu sebaliknya apabila seorang pemain tidak memiliki daya ledak otot tungkai, kelentuka dan keseimbangan yang baik maka kemampuan tendangan depan juga tidak akan baik. Dengan demikian agar kemampuan tendangan depan meningkat lebih baik maka perlu dilakukan latihan daya ledak otot tungkai, kelentukan dan keseimbangan secara teratur.

\section{KESIMPULAN}

Berdasarkan hasil dari penelitian yang telah dijabarkan dapat ditarik kesimpulan sebagai berikut: daya ledak otot tungkai berkontribusi dengan kemampuan tendangan depan atlet perguruan silat Tangan Mas Lubuk Basung dengan kontribusi sebesar 33\%. Kelentukan berkontribusi dengan kemampuan tendangan depan atlet perguruan silat Tangan Mas Lubuk Basung dengan kontribusi sebesar 32\%. Keseimbangan berkontribusi dengan kemampuan tendangan depan atlet perguruan silat Tangan Mas Lubuk Basung 
Rezhi Dwi Andri Zona ${ }^{1}$, M.Ridwan ${ }^{2 *}$, Suwirman ${ }^{3}$, Ronni Yenes ${ }^{4}$

Kontribusi Daya Ledak Otot Tungkai, Kelentukan dan Keseimbangan terhadap Kemampuan Tendangan

Depan Atlet Perguruan Silat Tangan Mas

dengan kontribusi sebesar 25\%. Daya ledak otot tungkai, kelentukan dan Keseimbangan secara bersama-sama berkontribusi dengan kemampuan tendangan depan atlet perguruan silat Tangan Mas Lubuk Basung, dengan kontribusi sebesar 63\%. Saran dari penulis untuk peneliti selanjutnya yang akan meneliti dengan variabel yang sama agar meneliti tentang faktor lain yang dapat meningkatkan keterampilan tendangan depan pada atlet pencak silat atau menemukan dan mengganti bentuk variasi baru dari bentuk tes masing-masing variabel.

\section{DAFTAR PUSTAKA}

Ambia, S., \& Ridwan, M. (2019). Korelasi Kelentukan Badan dan Daya Ledak Otot Tungkai Terhadap Kemampuan Smash Atlet Bolavoli Klub Padang Adios. Jurnal Patriot, 1(1).

Aziz, I., \& Donie, D. (2017). Profil Kondisi Fisik Mahasiswa Fakultas Ilmu Keolahragaan Universitas Negeri Padang. Jurnal Peforma Olahraga, 2(02), 132-142.

Chan, F., \& Aziz, I. (2020). Motivasi Atlet Pencak Silat Pusat Pendidikan Latihan Pelajar (PPLP) Sumbar. Jurnal Patriot, 2(1), 120-128.

Dadebo, B., White, J., \& George, K. (2004). A Survey of Flexibility Training Protocols and Hamstring Strains in Profesional Football Clubs in England. British Journal of Sports Medicine, 8, 793-793.

Gusfa, G., \& Ridwan, M. (2018). Kontribusi Daya Ledak Otot Tungkai Dan Kekuatan Otot Lengan Terhadap Kecepatan Renang Gaya Bebas 50 Meter Atlet Renang Tirta Kaluang Padang. Jurnal Patriot, 160-166.

Hardiansyah, S. (2019). Kontribusi Daya Tahan Kekuatan Dan Daya Ledak Otot Tungkai Terhadap Kemampuan Tendangan Depan Atlet Pencak Silat Unit Kegiatan Olahraga UNP. Jurnal Menssana, 1(2), 61-67.

Haryanto, J., \& Welis, W. (2019). Minat Berolahraga pada Kelompok Usia Middle Age. Jurnal Peforma Olahraga, 4(02), 214-233.

Hidayat, K., \& Argantos. (2020). Peran Usaha Kesehatan Sekolah (Uks) Sebagai Proses Prilaku Hidup Bersih Dan Sehat Peserta Didik. Jurnal Patriot, 2(2), 627-639.

Hunter, J. P., \& Marshall, R. N. (2002). Effects of power and flexibility training on vertical jump technique. Med. Sci. Sports Exerc, 34(3), 478-486. 
Rezhi Dwi Andri Zona ${ }^{1}$, M.Ridwan², ${ }^{2}$ Suwirman ${ }^{3}$, Ronni Yenes ${ }^{4}$

Kontribusi Daya Ledak Otot Tungkai, Kelentukan dan Keseimbangan terhadap Kemampuan Tendangan

Depan Atlet Perguruan Silat Tangan Mas

Ihsan, N., Zulman, Z., \& Adriansyah, A. (2018). Hubungan Daya Ledak Otot Tungkai dan Dayatahan Aerobik Dengan Kemampuan Tendangan Depan Atlet Pencak Silat Perguruan Pedang Laut Pariaman. Jurnal Peforma Olahraga, 3(01), 1.

Mahandra, S., \& Ridwan, M. (2019). Latihan Bola Gantung Berpengaruh Terhadap Kemampuan Servis Sepaktakraw. Jurnal Patriot, 1(2), 851-858.

Maidarman, M. (2016). Kontribusi Kekuatan Otot Tungkai, Kelentukan Pinggang, Dan Keseimbangan Terhadap Kemampuan Start Renang Gaya Kupu-Kupu Pada Mahasiswa. Jurnal Peforma Olahraga, 1(02), 147-156.

Maizan, I., \& Umar. (2020). Profil Kondisi Fisik Atlet Bolavoli Padang Adios Club. Jurnal Peforma Olahraga, 5(01), 12-17.

Nurahman, F., \& Ridwan, M. (2019). Pengaruh Variasi Latihan Passing Berkelompok Terhadap Kemampuan Chest Pass. Jurnal Patriot, 1(2), 715-724.

Putra, A., \& Afrizal. (2020). Kontribusi Kelentukan Dan Dayaledak Otot Tungkai Terhadap Heading Sepakbola. Jurnal Patriot, 2(2), 616-626.

R, F.-U., D, F.-U., \& Syampurma, H. (2019). Hubungan Kelincahan Dan Daya Ledak Otot Tungkai Terhadap Kecepatan Tendangan Sabit Atlet Pencak Silat Silaturahmi Kalumbuk Kecamatan Kuranji Kota Padang. Jurnal Menssana, 4(1), 44-52.

Ricotti, L. (2011). Static and dynamic balance in young athletes. Journal of Human Sport and Exercise, 6(4), 616-628.

Ridwan, M., \& Sumanto, A. (2017). Kontribusi Daya Ledak Otot Tungkai, Kecepatan Dan Kelentukan Dengan Kemampuan Lompat Jauh. Jurnal Peforma Olahraga, 2(01), 69-81.

S, A. (2018). Dayaledak Otot Tungkai Dan Kelentukan Berkontribusi Terhadap Akurasi. Jurnal Peforma Olahraga, 3(02), 81.

Sands, W. A., Mcneal, J. R., Stone, M. H., Russell, E. M., \& Jemni, M. (2006). Flexibility Enhancement with Vibration: Acute and Long-Term. Med. Sci. Sports Exerc, 38(4), 720-725.

Sepriadi, s., \& Neldi, H. (2018). Kontribusi Status Gizi Terhadap Kesegaran Jasmani. Jurnal Peforma Olahraga, 3(01), 60. 
Rezhi Dwi Andri Zona ${ }^{1}$, M.Ridwan², Suwirman ${ }^{3}$, Ronni Yenes ${ }^{4}$

Kontribusi Daya Ledak Otot Tungkai, Kelentukan dan Keseimbangan terhadap Kemampuan Tendangan Depan Atlet Perguruan Silat Tangan Mas

Solissa, J. (2017). Hubungan Status Gizi Dan Kemampuan Motorik Terhadap Prestasi Belajar Renang Mahasiswa Program Studi Penjaskesrek Fkip Universitas Pattimura Ambon. Jurnal Menssana, 2(1), 65-73.

Stockbrugger, \& Haennel. (2003). Contributing Factors to Performance of a Medicine Ball Explosive Power Test: A Comparison Between Jump and Nonjump Athletes. Journal of Strength and Conditioning Research, 17(4), 768-774.

Wahyuni, S., \& Donie, D. (2020). VO2MAX, Daya Ledak Otot Tungkai, Kelincahan Dan Kelentukan Untuk Kebutuhan Kondisi Fisik Atlet Taekwondo. Jurnal Patriot, 2(2), 640-653.

Yenes, R. (2018). Pengaruh Daya Ledak Otot Tungkai Dan Keseimbangan TerhadapKemampuan Jump Shot Atlet BolaBasket FIK UNP. Jurnal Performa, 3(02), 119.

Zulfahmi, z., Padli, P., Alnedral, A., \& Sari, D. (2020). Pengaruh Latihan Memukul Bola Digantung Terhadap Ketepatan Smash Open. Jurnal Patriot, 2(3), 757-768. 